\title{
Improvement of the Ability of High School Physics Teachers in Tanah Datar District in the Making of Teaching Materials with Scientific Literacy
}

\author{
Hidayati, Wahyuni Satria Dewi, Mairizwan \\ Jurusan Fisika, Fakultas Matematika dan Ilmu Pengetahuan Alam, Universitas Negeri Padang, Jl. Prof. Dr. Hamka Air \\ Tawar, Indonesia \\ *hidayati@fmipa.unp.ac.id
}

Diterima 7 Desember 2019, Disetujui 21 Maret 2020, Dipublikasikan 31 Maret 2020

\begin{abstract}
Abstrak - Pengajaran di sekolah harus dilaksanakan sesuai Kurikulum yang berlaku. Namun, kondisi nyata menunjukkan bahwa dalam melaksanakan Kurikulum 2013 revisi 20017, ada beberapa masalah. Salah satu solusi dari masalah yang ada adalah mengembangkan bahan ajar fisika bermuatan literasi saintifik pada guru Fisika SMA di kabupaten Tanah Datar. Tujuan dari kegiatan ini adalah untuk membantu guru Fisika SMA di kabupaten Tanah Datar dalam mengembangkan bahan ajar fisika bermuatan literasi saintifik. Peserta adalah 34 guru fisika SMA yang menjadi anggota MGMP fisika SMA di kabupaten Tanah Datar. Instrumen untuk mengumpulkan data terdiri dari pretes dan postes, lembar validasi bahan ajar. Data dianalisis dengan analisis statistik deskriptif dan uji perbandingan berkorelasi. Berdasarkan hasil analisis data dapat dinyatakan bahwa: 1). Dalam melaksanakan PKM, ada 12 bahan ajar yang dihasilkan dalam bentuk bahan ajar bermuatan literasi saintifik, 2). Bahan ajar bermuatan literasi saintifik yang ditulis guru-duru adalah valid, dan 3). Implementasi pengembangan bahan ajar bermuatan literasi saintifik dapat diklasifikasikan efektif untuk meningkatkan pemahaman guru sains pada materi bahan ajar.
\end{abstract}

Keywords — Instructional material, Scientific literacy,

\section{Pendahuluan}

Di abad ke 21 ini, pendidikan menjadi semakin penting untuk menjamin peserta didik memiliki keterampilan belajar dan berinovasi, keterampilan menggunakan teknologi dan media informasi, serta dapat bekerja, dan bertahan dengan menggunakan keterampilan untuk hidup (life skills). Abad 21 juga ditandai dengan banyaknya (1) informasi yang tersedia dimana saja dan dapat diakses kapan saja; (2) komputasi yang semakin cepat; (3) otomasi yang menggantikan pekerjaanpekerjaan rutin; dan (4) komunikasi yang dapat dilakukan dari mana saja dan kemana saja [1].

Keterampilan abad 21 ke dalam empat kategori berikut: (1) cara berpikir: kreativitas dan inovasi, berpikir kritis, pemecahan masalah, pengambilan keputusan, dan belajar bagaimana belajar (atau metakognisi), (2) cara kerja: komunikasi dan kerja sama dalam kelompok, (3) alat untuk kerja: pengetahuan umum dan literasi teknologi komunikasi informasi (ICT), (4) Hidup sebagai warganegara: kehidupan dan karir, dan tanggung jawab pribadi dan sosial, termasuk kesadaran budaya dan kompetensi[2].

Untuk meningkatkan kualitas pendidikan di Indonesia, pemerintah melalui departemen pendidikan dan kebudayaan selalu melakukan revisi kurikulum yang sekarang sudah berlaku Kurikulum 2013 revisi 2017 untuk semua jenjang pendidikan. Namun dalam implementasinya, kurikulum 2013 mengalami beberapa perubahan. Berdasarkan hasil monitoring dan evaluasi serta masukan publik, terdapat beberapa masukan yang menjadi perubahan dalam kurikulum 2013, antara 
lain adanya pemahaman yang kurang tepat oleh masyarakat yang diakibatkan oleh format penyajian dan nomenklatur dalam Kurikulum 2013: (1) Kompetensi Dasar (KD) pada Kompe tensi Inti 1 (KI-1) dan KD pada KI-2 yang dianggap kurang logis dikaitkan dengan karakte ristik mata pelajaran; (2) terindikasi adanya inkonsistensi antara KD dalam silabus dan buku teks (baik lingkup materi maupun urutannya); (3) belum ada pernyataan eksplisit dalam dokumen kurikulum tentang perlunya peserta didik lebih melek teknologi; (4) format penilaian dianggap terlalu rumit dan perlu penyederhanaan; (5) penegasan kembali pengertian pembelajaran saintifik yang bukan satu-satunya pendekatan dalam proses pembelajaran di kelas; (6) penyelerasan dan perbaikan teknis buku teks pelajaran agar mudah dipelajari oleh peserta didik.

Berdasarkan permasalahan-permasalahan di atas, maka penulis tertarik untuk mengatasi permasalahan guru dalam implementasi kurikulum 2013 ini pada nomor 6 yaitu tentang perbaikan buku teks pelajaran atau pada bahan ajar. Berdasarkan observasi terhadap buku teks yang beredar dipasaran saat ini belum sepenuhnya bisa memenuhi kriteria kurikulum 2013 revisi 2017 yang mengembangkan ketram pilan abad 21 (ketrampilan 4C) yang terdiri dari keterampilan berpikir kritis dan pemecahan masalah (Critical Thinking and Problem Solving Skills), keterampilan berkolaborasi (Collabora tion Skills), keterampilan berkreasi (Creativities Skills), dan keterampilan berkomunikasi dan memperhatikan kemampuan berpikir tingkat rendah (Lower Order Thinking Skills (LOTS)) sampai kemampuan berpikir tingkat tinggi (Higher Order Thinking Skills (HOTS)).

Pembelajaran yang baik meliputi beberapa unsur : (1) siswa yang belajar, (2) guru yang mengajar, (3) bahan pelajaran, (4) hubungan antara guru dan siswa. Ditinjau dari bahan pelajaran, guru diharapkan menguasai bahan yang mau diajarkan, dan dapat menyusun bahan sehingga materi mudah ditangkap oleh siswa [3]. Bahan ajar yang digunakan guru berfungsi sebagai acuan dalam pelaksanaan proses pembelajaran. Dengan penggunaan bahan ajar ini diharapkan aktivitas pembelajaran menjadi lancar. Disamping itu guru mengetahui dengan baik materi apa yang akan diajarkan dan dengan metode apa sebaiknya diberikan pada siswa untuk mencapai tujuan pembelajaran. Bagi siswa bahan ajar berfungsi sebagai acuan untuk mengetahui materi apa yang akan dipelajari dan siswa dapat belajar sesuai dengan cara mereka sendiri [4]. Salah satu penggunaan bahan ajar dalam pembelajaran adalah bahan ajar berbasis pendekatan saintifik. Penggunaan bahan ajar berbasis pendekatan saintifik melalui ICT dapat peningkatan hasil belajar siswa yaitu adanya peningkatan sebelum dan sesudah pembelajaran menggunakan bahan ajar [5].

Merancang pembelajaran yang mengaktifkan dan menarik peserta didik untuk mengembang kan ketrampilan 4C tentunya dibutuhkan racikan bumbu diantaranya penggunaan pendekatan pembelajaran yang tepat, media pembelajaran pendukung, dan buku ajar yang lengkap. Buku pembelajaran yang menarik bagi peserta didik salah satunya adalah buku pembelajaran yang bisa mengarahkan siswa untuk berfikir kritis dan pemecahan masalah.

Oleh sebab itu, dalam rangka mengimple mentasikan pelaksanaan kurikulum 2013 revisi 2017 (kurikulum Nasional) di SMA dan untuk memenuhi tuntutan kurikulum, kami tim PKM tertarik untuk membantu guru-guru untuk merancang bahan ajar berorientasi pada literasi scientifik untuk pembelajaran fisika SMA.

\section{Solusi/Teknologi}

Upaya untuk mengatasi permasalahan dalam menerapkan pembelajaran yang mengintegrasikan literasi perlu dilakukan. Salah satu solusi yang dapat ditawarkan untuk memecahkan permasa lahan mitra adalah "Pelatihan Pembuatan Bahan Ajar Fisika SMA Bermuatan Literasi Saintifik di MGMP Fisika SMA Di Kabupaten Tanah Datar".

Landasan teori yang berhubungan dengan solusi adalah bahan ajar. Bahan ajar diperlukan untuk menciptakan proses pembelajaran yang efektif. Bahan ajar merupakan seperangkat materi yang disusun secara sistematis, menampilkan sosok utuh kompetensi yang akan dikuasai oleh siswa dalam kegiatan pembelajaran [6]. Bahan ajar memiliki fungsi strategis dalam proses pembelajaran. Bahan ajar dapat membantu guru 
dan siswa dalam kegiatan pembelajaran sehingga guru tidak terlalu banyak menyajikan materi Bahan ajar bagi guru dapat menghemat waktu dalam pembelajaran, dan meningkatkan proses pembelajaran menjadi lebih efektif dan interaktif [7]. Bagi siswa peran bahan ajar dapat mengurangi ketergantungan pada guru dalam belajar, dapat belajar tanpa harus dibatasi oleh waktu dan tempat, dapat belajar sesuai dengan kecepatan sendiri, dan membantu potensi untuk menjadi pembelajaran mandiri.

Teori berikutnya adalah tentang literasi. Literasi adalah kemampuan individu untuk membaca, menulis, berbicara, menghitung, dan memecahkan masalah pada tingkat keahlian yang diperlukan dalam pekerjaan, keluarga, dan masyarakat. Literasi saintifik adalah pemahaman atas sains dan prosesnya, serta mampu meng aplikasikannya dalam kebutuhan masyarakat. Literasi saintifik didefenisikan sebagai kapasitas untuk menggunakan pengetahuan ilmiah. Jadi, literasi saintifik merupakan pengetahuan dan pemahaman tentang konsep ilmiah dan proses yang diperlukan bagi seseorang untuk menemu kan atau menentukan jawaban pertanyaan dari rasa ingin tahu tentang pengalaman sehari-hari.

Literasi saintifik memiliki tiga indikator, yaitu konsep saintifik, proses saintifik, dan konteks saintifik. Melalui literasi saintifik dapat meningkatkan pemahaman konsep dan penerapan materi dalam kehidupan sehari-hari [8]. Konsep saintifik merupakan pengetahuan ilmiah atau konsep yang diperlukan untuk memahami fenomena alam dan perubahan yang dilakukan manusia terhadap alam melalui aktivitasnya

Pendekatan yang digunakan untuk merealisasikan solusi yang diajukan untuk menyelesaikan masalah pada guru-guru Fisika di MGMP Fisika SMA Kabupaten Tanah Datar (sebagai mitra PKM), adalah pendekatan individual dan klasikal. Pendekatan klasikal dilakukan pada saat pemberian teori tentang Konsep Kurikulum 2013 revisi 2017 dan pembelajaran abad 21 dan pendekatan individual dilakukan pada saat Analisis Materi Ajar dan pembuatan bahan ajar yaitu latihan membuat bahan ajar bermuatan literasi saintifik . Untuk itu pelaksanaan kegiatan PKM dilakukan melalui lima tahap. Tahapan yang dilaksanakan yaitu tahap orientasi, tahap persiapan pelaksanaan, tahap pelaksanaan, tahap monitoring dan evaluasi dan tahap analisis data dan pembuatan laporan.

Secara rinci tahapan kegiatan, jenis kegiatan tempat pelaksanaan kegiatan dapat dilihat pada Tabel 1

Tabel 1. Tahap-Tahap Kegiatan dan Tempat Pelaksanaannya

\begin{tabular}{cll}
\hline \multicolumn{3}{c}{ Kegiatan } \\
\hline Tahapan & \multicolumn{1}{c}{ Jenis } & \multicolumn{1}{c}{ Tempat } \\
\hline I & Tahap orientasi & $\begin{array}{l}\text { Laboratorium } \\
\text { PBM UNP dan } \\
\text { SMAN 1 } \\
\text { Salimpaung }\end{array}$ \\
\hline II & $\begin{array}{l}\text { Tahapan } \\
\text { persiapan } \\
\text { pelaksanaan }\end{array}$ & $\begin{array}{l}\text { Laboratorium } \\
\text { PBM UNP }\end{array}$ \\
\hline III & $\begin{array}{l}\text { Tahapan } \\
\text { pelaksanaan }\end{array}$ & $\begin{array}{l}\text { SMAN 1 } \\
\text { Salimpaung }\end{array}$ \\
\hline IV & $\begin{array}{l}\text { Tahapan } \\
\text { monitor ring } \\
\text { dan evaluasi }\end{array}$ & $\begin{array}{l}\text { SMAN 1 } \\
\text { Sungayang }\end{array}$ \\
\hline V & $\begin{array}{l}\text { Analisis data } \\
\text { dan pembuatan } \\
\text { laporan }\end{array}$ & $\begin{array}{l}\text { Laboratorium } \\
\text { PBM UNP }\end{array}$ \\
\hline
\end{tabular}

Pada tahap pelaksanaan di lokasi MGMP Fisika SMA Kabupaten Tanah Datar yaitu di SMAN 1 Salimpaung. Peserta yang mengikuti kegiatan pada tahapan ke III ini seperti terlihat pada Gambar 1

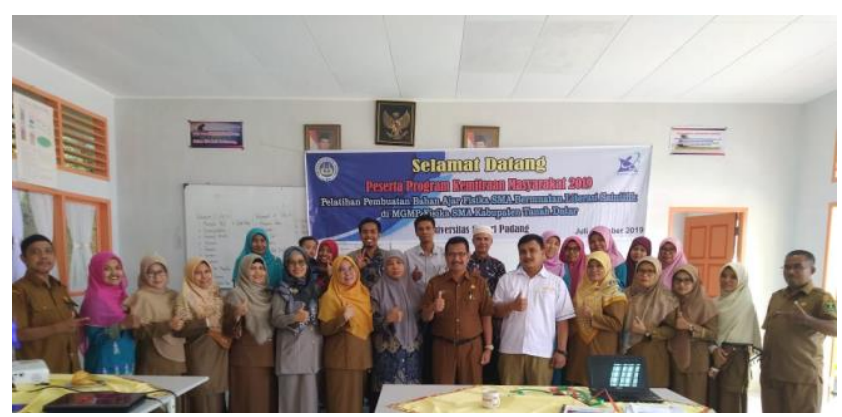

Gambar 1. Peserta Kegiatan

\section{Hasil dan Diskusi}

Bahan ajar Fisika SMA bermuatan literasi saintifik yang ditulis peserta memiliki struktur 
yaitu (1). Cover (2) Kata Pengantar, (2) Daftar Isi, (4) Petunjuk Belajar (5). Kompetensi yang Akan Dicapai (6). Materi Pembelajaran (7), Informasi Pendukung (8) Latihan. Lembar Kerja. Meliputi Konteks Saintifik, Proses Saintifik dan Konsep Saintifik (9) Evaluasi. Hal ini dapat dilihat di sampel pada Gambar 2
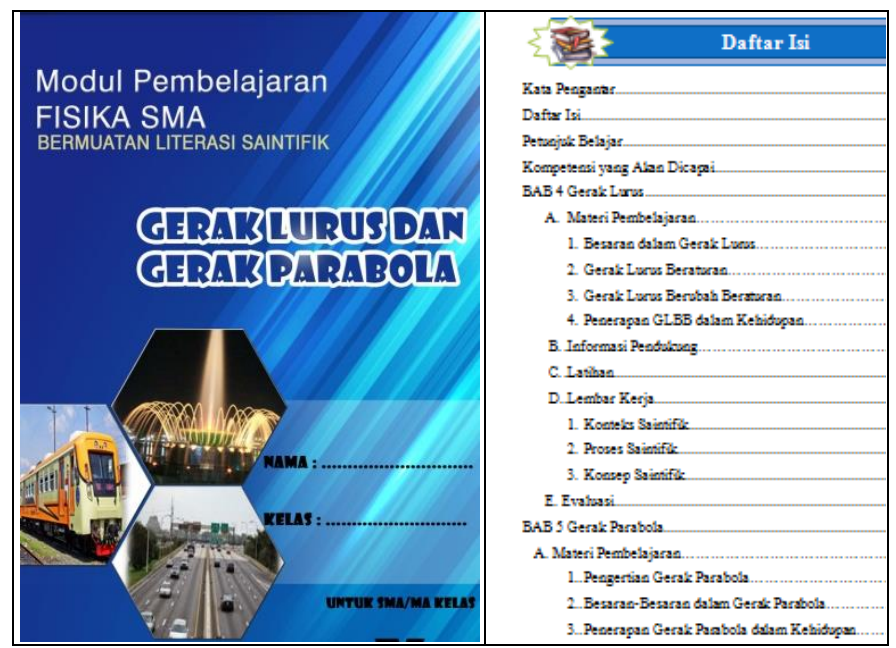

Gambar 2. Sampel Cover dan Daftar Isi Bahan Ajar

\section{Validitas Bahan Ajar}

Hasil pertama dari kegiatan ini adalah produk dari peserta. Sebagai produk dari kegiatan ini adalah berupa bahan ajar Fisika SMA bermuatan literasi saintifik. Dalam kegiatan ini telah dihasilkan 12 produk bahan ajar. Bahan ajar yang di hasilkan guru ada berupa Modul Pembelajaran, Bahan Ajar dan Lembar Kegiatan Siswa (LKS). Dari sampel produk bahan ajar yang telah dihasilkan oleh peserta dilakukan validasi menggunakan lembar penilaian validasi bahan ajar. Hasil validasi diperlihatkan pada Gambar 3.

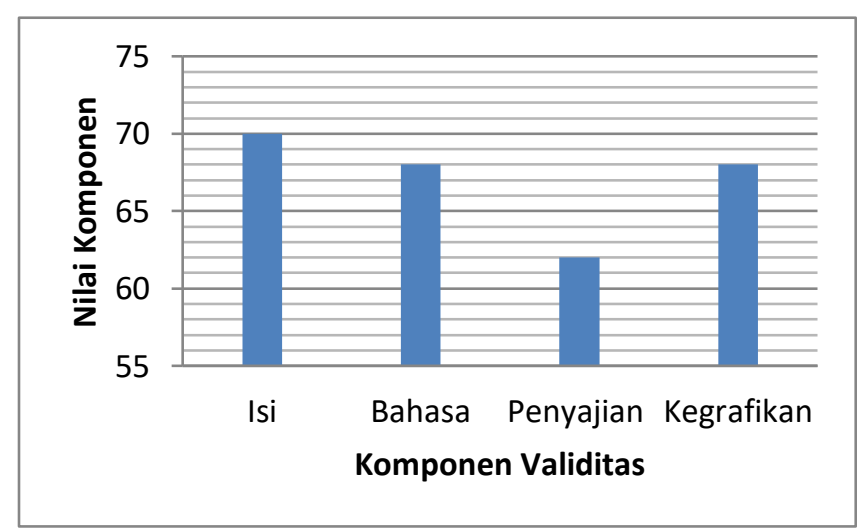

Gambar 3. Nilai Validitas Bahan Ajar
Gambar 3 memberi penjelasan bahwa penilaian validitas terhadap produk menggunakan empat komponen validasi yaitu komponen kelayakan isi dari produk, komponen kebahasaan, komponen penyajian dan komponen kegrafikan. Dari hasil validasi terhadap komponen kelayakan isi dari sampel produk bahan ajar mencapai nilai rata-rata 70. Nilai rata-rata tersebut dapat dikategorikan ke dalam kriteria valid. Dari komponen kebahasaan dari produk bahan ajar yang dihasilkan didapatkan data bahwa nilai rata-ratanya 68 dengan kriteria valid. Untuk komponen penyajian nilai rata-rata adalah 62. Nilai rata-rata ini dapat dikategorikan ke dalam kriteria valid. Selanjutnya nilai rata-rata untuk komponen kegrafikan 68, dengan kriteria valid.

\section{Efektivitas Kegiatan}

Efektivitas dari kegiatan penulisan bahan ajar fisika bermuatan literasi saintifik ditentukan dari perbandingan antara penguasaan peserta setelah dengan sebelum kegiatan. Nilai pengua saan materi peserta terhadap bahan ajar ini diperoleh dari lembaran soal pretes yang diberikan pada peserta sebelum kegiatan dan lembaran postes yang diberikan pada peserta setelah kegiatan.

Data hasil pretes dan postes peserta diolah untuk menentukan efektivitas dari kegiatan. Pengolahan data seperti pada Tabel 2

Tabel 2. Analisis Data Penguasaan Peserta

\begin{tabular}{llcc}
\hline No & Parameter & Pretes & Postes \\
\hline 1 & Nilai rata-rata & 49,08 & 76,7 \\
\hline 2 & Standar deviasi & 7,9 & 9,2 \\
\hline 3 & Variansi & 63 & 78 \\
\hline 4 & $\begin{array}{l}\text { Nilai t uji } \\
\text { perbandingan } \\
\text { berkorelasi }\end{array}$ & \multicolumn{2}{c}{$-17,06$} \\
\hline 5 & Nilai t tabel & \multicolumn{2}{c}{$-2,00$} \\
\hline
\end{tabular}

Berdasarkan Tabel 2 didapatkan data nilai ratarata pretes peserta kegiatan mengalami kenaikan yaitu dari 49,08 menjadi 76,7. Nilai $t$ uji perbandingan berkorelasi berada diluar derah penerimaan hipotesis Ho. Dengan kata lain, kegiatan PKM penulisan bahan ajar Fisika bermuatan literasi saintifik memberikan pengaruh yang berarti terhadap penguasaan materi dari 
peserta. Dapat dikatakan bahwa kegiatan PKM yang dilakukan di MGMP Guru Fisika SMA Kabupaten Tanah Datar efektif.

\section{Kesimpulan}

Kesimpulan mengungkapkan hal yang lebih tinggi atau luas dari diskusi. Hendaknya dalam bagian ini terkandung penarikan kesimpulan dan perampatan yang meluas, serta pencetusan teori, konsep, prinsip baru secara mapan daripada kesimpulan dangkal dan saran yang menyatakan kegiatan PkM yang perlu dilanjutkan.

\section{Ucapan Terima Kasih}

Program PKM ini dapat dilaksanakan dengan baik karena adanya bantuan dari berbagai pihak. Dengan alasan ini, kami mengucapkan terima kasih kepada: 1). Rektor UNP dan Ketua LP2M yang telah memberikan hibah Program Kemitraan Masyarakat, 2). Kepala Sekolah SMAN 1 Salimpaung dan Kepala Sekolah SMA Negeri 1 Sungayang yang telah memberikan fasilitas tempat untuk melaksanakan program PKM, 3). Ketua MGMP Fisika SMA kabupaten Tanah Datar yang telah memfasilitasi pelak sanaan program PKM, dan 4). guru-guru Fisika anggota MGMP Fisika SMA kabupaten Tanah Datar yang telah terlibat secara aktif dalam kegiatan program PKM.

\section{Pustaka}

[1] Litbang Kemdikbud, 2013) Kemdikbud. 2013. Lampiran Peraturan Menteri Pendidikan dan Kebudayaan Republik Indonesia Nomor 65 Tahun 2013 tentang Standar Proses Pendidikan Dasar dan Menengah

[2] Saavedra, A.R., \& Opfer, V.D. (2012). Teaching and Learning 21 st Century Lesson from the Learning Sciences. Asia Society, Partnership for Global Learning. 1-35.

[3] Suparno, Paul. 2007. Metodologi Pembelajaran Fisika. Yogyakarta : Universitas Sanata Dharma.

[4] Prastowo, Andi. 2011. Bahan Ajar Inovatif. Jogjakarta: Diva Press.

[5] RP Yenni, M Masril, Hidayati 2016 Pengaruh Penerapan Bahan Ajar Berbasis Pendekatan Saintifik Melalui ICT Dalam Model Pembelajaran Inquiry Terhadap Kompetensi Fisika Siswa Kelas X SMA N 1 Padang. Pillar of Physics Education 7 (1)

[6] Sukmawati, Fatma. 2015. Pengembangan Bahan Ajar Biologi Berbasis Contextual Teaching and Learning untuk Mengefektifkan Pembelajaran Bagi Siswa SMA. Fenomena, Volume 7, No. 1

[7] Murniati, dan Yusup. 2015. Pengembangan Bahan Ajar Mata Kuliah Laboratorium Fisika Sekolah Berdasarkan Kompetensi. Jurnal Inovasi dan Pembelajaran Fisika, Volume 2, Nomor 2

[8] Utami, B. 2016. Scientific Literacy In Science Lesson. (1) Jurnal prosiding ICTTE FKIP UNS. Hlm. 125-133 (Utami, B. 2016). 